\title{
The Teaching Practice of the Cross-Border E-Commerce to Business English Majors in Vocational and Technical Colleges: A Study Based on the Theory of CLIL \\ Yi Jing \\ Luojia College, Wuhan University, 430000
}

\begin{abstract}
In order to make the teaching practice in the business English major in vocational and technical colleges meet with the new requirements of cross-border e-commerce for business English majors, the theory of CLIL needs to be used in business English teaching process. Compared with the traditional teaching approaches which have caused many current problems, the theory of CLIL can be really beneficial for the colleges, e-business companies and students as it integrates international e-business skills and English language teaching together.
\end{abstract}

Keywords- CLIL; cross-border e-commerce; business English major

\section{INTRODUCTION}

CLIL - Content and Language Integrated Learning, which is inspired by important methodological principles such as the need for learners to be exposed to a situation calling for genuine communication, enables languages to be taught on a relatively intensive basis without claiming an excessive share of school timetable.

CLIL programs combine teaching content from a curriculum area with the explicit teaching of the target language. (1) There is a focus on the vocabulary and structures required for the additional curriculum area. Content may include all or part of one or more curriculum areas. In a CLIL program, learners gain knowledge of the curricular subject (for example, Business or E-Commerce) while simultaneously learning and using the target language (for example, English). CLIL has the advantage of addressing the "crowded curriculum"(2) issue as it enables one or more curriculum areas to be taught in and through an additional language, and thereby extends the time on task for language learning.

CLIL goes beyond aiming for development of types of lower-order thinking skills towards higher-order skills, through which CLIL is differentiated from other types of content-oriented language learning approaches, and exposes students to more practical atmospheres, so as to cultivate them to be inter-disciplinary with professional and foreign language skills.

\section{The New Requirements of Cross-Border E-Commerce to English Teaching for Business English Majors}

For a long time, in the process of the development of China's export-oriented economy, a big amount of business English majors has been trained in China as a group of professionals engaged in the international e-business field. In recent years, the employment situation in the traditional international trade industry is severe, because of which business English majors' employment has been influenced in a certain degree. However, the vigorous development of cross-border e-commerce brought a new dawn for the foreign trade industry, and there are increasingly more companies shifting from traditional foreign trade to the cross-border e-commerce. It is reported that in 2013 China's traditional foreign trade grew by less than $10 \%$, the cross-border 
e-commerce, however, at a speed of more than $30 \%$ on the rise ${ }^{3}$, the market appeared a huge demand for cross-border e-commerce professionals.

Therefore, the education to business English majors in vocational and technical colleges should also adapt to the market demand, and, under the background of the new situation of cross-border e-commerce, cultivate professionals who can meet the need of the enterprises, the cross-border e-commerce industry, and the regional and national development. The teaching of English courses, which are the basic courses for business English majors, must also take the requirements of students' future occupation into consideration, and integrate international e-business skills and English language education together.

\section{The Plight of Conventional Instruction in Business English Major}

Business English, which belongs to ESP (English for Special Purpose), has a special feature as being really professional, informative, and practical. Based on this point, it is critical and necessary to contain it into the teaching materials and contents that of the practical training of English communication, which will be probably used under the circumstances of doing international e-business in the cross-border e-commerce industry. The following aspects $^{(4)}$ are the deficiencies embodied in the present teaching practice of the cross-border e-commerce courses to business English majors in vocational and technical colleges.

\subsection{Lack of Practical Training in Teaching}

Generally, in many colleges, the set of practical training courses in business English is not enough; there are certain gaps in the curriculum of business English major with the actual demand of enterprises; The handle the relationship between the business skills, knowledge and the language ability is not proper, by simply placing the language classes and business classes together, which focuses too much more on the language teaching but neglects the practical operations of cross-border e-commerce and other international business skills, or vice versa. It is from these points that the students are lack of the opportunities to learn and use practical professional knowledge and skills.

\subsection{Lack of Textbooks and Teaching Materials in the Practical Training}

Till now, the textbooks and teaching materials in business English courses for business English majors are highly theoretical, focus on e-commerce vocabulary, or the format of the foreign trade correspondence and sentence patterns, with relatively old contents and seldom make it available that there are the training materials of knowledge and skills required by the cross-border e-commerce practical operations.

\subsection{Students' Lack of Confidence and Initiative in Learning}

Students in vocational and technical colleges have commonly got a weak English foundation, so it is relatively difficult for them to understand the textbooks, because of which most of them lack of confidence and initiative in learning their professional knowledge and the English, thus gives obstructions for their teachers while teaching them.

\section{The Usage of CLIL in the Teaching Practice in the Business English Major in Vocational and Technical Colleges}

By using the theory of CLIL in business English teaching, teachers and students will pay more attention to the integration of English 
language skills and achieve mastery with comprehensive business professional knowledge, since the CLIL emphasizes both subject contents and language skills. The specific application of the CLIL includes the contents as follows.

\subsection{To Lay a Solid Foundation of Students' Language and Focus the Theoretical Study on the Process of Business Negotiation in the}

\section{Cross-Border E-Commerce}

Foreign language teaching should focus on those frequently-used vocabulary, sentence patterns and expressions specialized in every link of import and export trade business. The teaching process of language be associated with the Aliexpress, DHgate, WISH and other cross-border e-commerce platforms, to help students to grasp the terms and expressions for business communication while doing practical cross-border e-commerce operating practices.

\subsection{To Make the Students Have Operating Practices Based on the Uses of Cross-Border E-Commerce Online Platforms}

Because, according to the curriculum arrangement, it is usually in the second year that business English courses start being delivered, teachers can encourage students to use their freshman year time to familiarize themselves with the operation of cross-border e-commerce, such as open an online shop by a single of a group of them, learn the skills of how to choose products, search for the suppliers, display the goods descriptions online, set up logistics templates, do the product promotion, handle the problems of the inquiries, counter-offers, delivery and after-sales service, etc.

\subsection{To Cooperate Closely with Cross-Border E-Commerce Enterprises and Construct the University-Enterprise Cooperation Platforms \\ In close cooperation between colleges and cross-border e-commerce enterprises, some}

well-known responsible persons of the cross-border e-commerce platforms should be invited to walk into the classroom to share and communicate with students about the new international market situation, the new information, and the cross-border e-commerce operation skills, as well as give lessons about how to deal with the problems, and provide practical guidance to students' operating stores. In the meanwhile, students can be arranged to visit the production line in factories so as to learn the operation of those companies, open their minds, and make students learn to think and give analysis about how to optimize and improve producing and e-business skills, thus the students can be well-educated to meet the professional post requirements in their future real work.

5 The Special Features and Innovation of English Teaching in the Business English Major by Applying the Theory of CLIL

5.1 Make up the Deficiency of the Over-Theoretical Teaching Materials and the Required Skills Training in Doing Business of Cross-Border E-Commerce

According to the theory of CLIL, the curriculum arrangement of teaching in business English major should combine teaching and cross-border e-commerce practice together, to make the English teaching in business English major in colleges closely integrated with the actual operation of cross-border e-commerce and the enterprises' demand, and at the same time, to construct the cooperation platforms of colleges and cross-border e-commerce enterprises, to invite experienced persons to teach regularly or share their experiences aperiodically, and to arrange students to visit the enterprises. By doing all of these, the students, who are well-trained for the professional skills, 
can surely satisfy the business enterprises actual demands.

\subsection{Improve the Students' Interest in} Learning and Enhance the Students' Learning Confidence and Initiative

By using the theory of CLIL, the theoretical teaching can be combined with the practical e-business operation, therefore students will put the terms and expressions of cross-border e-commerce they have mastered in to real practices. This, to a large extent, can certainly inspire students learning initiative and enthusiasm, improve their learning confidence, so as to change the traditional passive learning into the future active learning.

\subsection{Cultivate the Students' Ability of Entrepreneurial Practice in Business of Cross-Border E-Commerce}

The above-mentioned teaching approach based on the theory of CLIL can help the students in business English major master the cross-border e-commerce entrepreneurial skills and knowledge, accumulate practical experiences in this field, thus to lay a solid foundation for their starting up with their own international e-business in the future.

\section{Conclusion}

In order to make the teaching practice in the business English major in vocational and technical colleges meet with the new requirements of cross-border e-commerce for business English majors, the theory of CLIL needs to be used in business English teaching process. According to the theory of CLIL, the curriculum arrangement of teaching in business English major should combine teaching and cross-border e-commerce practice together, to make the English teaching in business English major in colleges closely integrated with the actual operation of cross-border e-commerce and the enterprises' demand, and at the same time, to construct the cooperation platforms of colleges and cross-border e-commerce enterprises. Our research analyzes the features of the related theories to propose our new idea for further optimization.

\section{ACKNOWLEDGEMENT}

This paper is one of the research achievements of the 2015 Hubei Education Scientific Planning Project"The Applied Research of Flipped Class Teaching Mode Based on Micro Lessons in English Teaching in Private Colleges". (Project Item no.: 2015G154)

\section{References}

[1] Christian Dalton-Puffer, Tarja Nikula. Language Use and Language Learning in CLIL Classrooms[M]. Amsterdam/Philadelphia: John Benjamins Publishing Company, 2010.

[2] Murphy J., Stoller F. Sustained Content Language Teaching: An Emerging Definition[J]. TESOL Journal, 2001(3): 3-5.

[3] Zhu Yangqiong. The Study of International Trade E-Commerce Mode Based on Aliexpress-Take Business English Major as an Example[J]. Study on Productivity, 2014(11): 103-105.

[4] Chen Hao, Ding Hongchao. On Reforming and Constructing Business English Program in Higher Vocational Education Based on International E-Business-Taking Guangzhou Panyu Polytechnic College as an Example $[\mathrm{J}]$. Journal of Yueyang Vocational Technical College, 2015(5): 78-81. 